\title{
Article
}

\section{'Cost' calculations as a barrier to gaining information under the Freedom of Information Act 2000 from the Police in England and Wales}

Kingston, Sarah, Elliott, Amy and Thomas, Terry

Available at http://clok.uclan.ac.uk/31280/

Kingston, Sarah ORCID: 0000-0002-9226-1915, Elliott, Amy and Thomas, Terry (2019) 'Cost' calculations as a barrier to gaining information under the Freedom of Information Act 2000 from the Police in England and Wales. Policing and Society: An International Journal of Research and Policy, 29 (7). pp. 834-847. ISSN 1043-9463

It is advisable to refer to the publisher's version if you intend to cite from the work. http://dx.doi.org/10.1080/10439463.2018.1424156

For more information about UCLan's research in this area go to http://www.uclan.ac.uk/researchgroups/ and search for <name of research Group>.

For information about Research generally at UCLan please go to http://www.uclan.ac.uk/research/

All outputs in CLoK are protected by Intellectual Property Rights law, including Copyright law. Copyright, IPR and Moral Rights for the works on this site are retained by the individual authors and/or other copyright owners. Terms and conditions for use of this material are defined in the policies page. 


\title{
'Cost' calculations as a barrier to gaining information under the Freedom of Information Act 2000 from the Police in England and Wales
}

\begin{abstract}
Previous research has identified the methodological value of using the Freedom of Information Act 2000 to gain access to information held by the police, as well as its limitations. Very little attention, however, has been paid to the ways in which the police calculate the cost of FOI compliance and utilise cost exemptions to deny access to information. In this article, we present our empirical findings from our FOI requests made to the police in England and Wales that demonstrates how cost calculations became a barrier to our request for information. In addition, the responses received show that there were significant differences between the calculated cost needed to retrieve the information, the reasons given for the refusal for access to information, as well as regional variations with FOI compliance. We argue that excessive cost calculations, given as a reason for not providing access to information by the police, is a 'metric' for institutional limitations in data recording and data management. Furthermore, in a time of 'austerity' we suggest that with increases in police funding cuts the calculated cost of FOI compliance will increase, thereby undermining police transparency and accountability. We therefore question claims that the FOIA is a 'powerful' tool that social researchers should use more often.
\end{abstract}

Key Words: Police, Freedom of Information Act 2000, cost calculations Word Count: 


\section{Introduction}

The UK Freedom of Information Act 2000 (FOIA) has been utilised by researchers to gain access to data held by the police which would previously have been unattainable. This Act provides the public with the ability to request access to information held by public authorities. Without the use of FOIA, access to this information would have been difficult to obtain, and thus it has led some to argue that it is a powerful tool that social researchers should use more often (Savage \& Hyde, 2013, 2014). Savage (2016), for example, gained access to 39 UK police constabularies' whistleblowing policy in 2015. FOI requests have been made to the police in the UK in order to determine the resources dedicated to respond to fraud and economic crimes (Button, Blackbourn \& Tunley, 2014); usage patterns of lesslethal forms of the Use of Force (Payne-James, Rivers, Green \& Johnston, 2014); and to determine the number of police station closures and reductions in opening hours (Smith $\&$ Somerville, 2013).

Yet despite these successes, previous research has also identified the problems of gaining access to information due to non-compliance with the Act, requests for further clarification and details of the request for information, as well as the variations in approaches to dealing with FOI by the police due to a lack of coordination (Savage \& Hyde, 2013; Savage, 2016). Likewise internationally, concerns have been raised about the exemptions and practices to restrict access to information under FOI laws in Canada (Roberts, 2005) the United States (Birkenshaw, 2010; Katz, 1970; Kronman, 1980; Nader, 1970; Uhl, 2003; Wasike, 2016) Mexico (Alamanzar et al, 2017) and Albania, Armenia, Indonesia, Jamaica, South Africa, and Ukraine (LaMay et al, 2013). Pertinently, access to data in England, Wales and Northern Ireland is limited in a number of ways under FOIA including a financial 'test' which stipulates that the retrieval of information that exceeds a financial threshold allows public authorities to decline a request for information. Previous research in Mexico has 
identified techniques officials use to deflect access to information such as how public bodies estimate cost calculations (Almanzar et al, 2017). Although, recognition has been made in this limited body of research to some constabularies utilisation of the 'cost' exemption to refuse disclosure (Savage \& Hyde, 2013), and that this is 'of interest' (Payne-James et al, 2014, p.53), this has yet to be examined in any depth.

This article seeks to address this absence and adds to this limited body of research by presenting our original data on the responses received to our FOI request on the use of ASBOs against sex workers in England and Wales. These findings illustrate how the 'cost' exemption that was introduced in the FOIA 2000 in England, Wales and Northern Ireland, is being used by the police as an explanation for non-disclosure of information under FOIA 2000. Our empirical data also shows that there are regional variations to the police's FOI compliance, as well as constabulary specific organisational barriers identified as the rationale for non-compliance. Instead, we claim that the 'cost' calculations made by the police are a 'metric' for institutional barriers related to data recording and data management. Thus, our research will be of interest internationally as researchers have begun to identify the barriers to obtain data from public bodies under FOI laws. This article will also tackle the thorny debates around police accountability and the transparency of public bodies and claim that with police funding cuts the calculated 'cost of FOI compliance increases. Furthermore, we interrogate claims that the FOIA is a 'powerful' tool that social researchers should use more often.

The article begins by examining the Freedom of Information Act 2000; its history, aims and rationale, and its formal stated ways of working. We then move on to our own experiences of the responses received from the police, and other agencies.

\section{The Freedom of Information Act 2000}


The UK's FOIA 2000 was proposed by New Labour and passed in a spirit of openness and transparency (Hazell et al, 2010). The laws introduction followed international trends that had seen anything up to 90 other countries passing similar laws (Worthy, 2010). On the wider front was the hope that the transforming power of knowledge and information about public bodies would lead to greater efficiency as they would be made more accountable and open to public scrutiny. By introducing FOI laws, it has been claimed that they enable citizens to gain a better understanding of decision making and how governments operate, as well as the possibility for public participation which may lead to increased public trust (Nader, 1970; Roberts, 2005). Information that had traditionally been secret was now supposedly available to any applicant subject to various limitations. However, the introduction of exemptions to FOI laws has undermined this ideological rationale.

Freedom of Information was a flagship policy of New Labour when it came to power in May 1997. It lost no time in outlining its ideas in the White Paper Your Right to Know: the government's proposals for a Freedom of Information Act (Duchy of Lancaster, 1997). The previous three Conservative governments had declined to entertain the idea (see Vincent 1998, p.302-4). The Freedom of Information Act covering England, Wales and Northern Ireland was passed in November 2000 and the Freedom of Information (Scotland) Act 2002 followed two years later. The Information Commissioners Office (ICO) was charged with oversight of the Act.

The Act provides public access to information held by public authorities. It does this in two ways:

- public authorities are obliged to publish certain information about their activities; and

- members of the public are entitled to request information from public authorities. 
Public authorities include government departments, local authorities, the NHS, state schools and police forces. Information includes printed documents, computer files, letters, emails, photographs, and sound or video recordings. ${ }^{1}$

The Freedom of Information Act requires all public authorities - including police constabularies - to respond to a request as soon as practicable, and in any case within 20 working days. If a police constabulary cannot immediately reply to a request, they should send an acknowledgement letter containing an estimated date by which the information will be ready. Day one of the life of a request is the first full working day after it is received by the force. The Department of Constitutional Affairs produced a Code of Practice for public authorities to follow when providing information (DCA, 2004). Appeals against noncompliance by the public body in question are initially made to the body concerned and then to the ICO and finally to the Information Tribunal if the requester is still not happy. The Information Commissioners Office (2015) has produced a guidance document specifically for the police on how they should present information.

\section{Refusing to provide information}

The Act recognises that freedom of information requests are not the only demand on the resources of a public authority and they should not be allowed to cause a drain on their time, energy and finances to the extent that they negatively affect an organisations normal public functions. In that context, in certain circumstances public authorities are allowed to refuse to provide information.

\footnotetext{
${ }^{1}$ The Act does not give people access to personal data about themselves or other identifiable people. Such information is covered by the relevant provisions of the Data Protection Act 1998.
} 
The Act allows public authorities to withhold information, for example, if the collation of the information is considered too costly (Freedom of Information Act, 2000 s.12). The Ministry of Justice Secretary of State will prescribe a threshold of the number of hours to be taken on the search. The Act allows the Secretary of State to prescribe different amounts for different authorities. The public authority can either stop looking when 'the appropriate amount' has been met or can charge for the costs of the further search if still required.

The Secretary of State has published Regulations that prescribe 'the appropriate amount' (The Freedom of Information and Data Protection (Appropriate Limit and Fees) Regulations 2004 No. 3244). These costs are based on the costs of the following activities:

- determining whether the information is held;

- finding the requested information, or records containing the information;

- retrieving the information or records; and

- extracting the requested information from records.

The biggest cost is likely to be staff time. In the case of the police the threshold is $£ 450$ based on staff working at $£ 25$ per person per hour. This means a limit of 18 staff hours for each FOI request. When a number of requests have been made by one person, the police like any other public authority may 'aggregate' the requests to take an overall view of the resources which are going to be required. Whether 'aggregated' or not, the police have a nationally agreed policy of not going beyond the 'appropriate amount' even if the requesting party is prepared to pay the additional costs (College of Policing, 2015). The police should still say whether they hold the information, even if they cannot provide the information itself under the cost ceiling. 


\section{The 2015 Review}

The excessive burden of FOI on public authorities was integral to a review of FOI in 2015. The Conservative government elected in 2015 announced a Commission to examine the FOI Act and consider if further restrictions should be imposed on the right to know (Lord Bridges, 2015). Its terms of reference were:

(to) review the Freedom of Information Act 2000 ('the Act') to consider whether there is an appropriate public interest balance between transparency, accountability and the need for sensitive information to have robust protection, and whether the operation of the Act adequately recognises the need for a 'safe space' for policy development and implementation and frank advice. The Commission may also consider the balance between the need to maintain public access to information, and the burden of the Act on public authorities, and whether change is needed to moderate that while maintaining public access to information (ibid; emphasis added).

The idea that the Act is a 'burden on public authorities' seems to undermine its spirit even before the Commission started its proceedings. ${ }^{2}$ Critics highlighted their concern that this review could lead to a watering down of FOIA (Connett, 2015). The case for strengthening the Act to allow more information to be disclosed was not on the agenda.

In a separate move, the Ministry of Justice proposed that there should be a $£ 100$ charge for appealing to the First-tier Tribunal against an Information Commission Office decision. An oral hearing would cost an additional $£ 500$. Appeals are currently free (MoJ, 2015a). Not

\footnotetext{
${ }^{2}$ The Commission was chaired by Lord Burns, and included the Rt Hon Jack Straw, Lord Howard of Lympne, Lord Carlile of Berriew and Dame Patricia Hodgson.
} 
surprisingly this led to a number of concerns raised by groups such as Campaign for Freedom of Information. The Ministry of Justice published the responses it got to its consultation document in December 2015 with most respondents saying costs should not be incurred for Freedom of Information appeals (see MoJ, 2015b: paras 56 and 60). The government decided to defer a decision until after publication of the Commission report (ibid: para 94) which eventually appeared 1 March 2016 (Cabinet Office 2016; see below).

The report made 21 recommendations but said nothing on changing the price of information. The Government made an immediate response and agreed with the Commission's view that the Act was working well, and that while somewhat minor administrative changes were required no legal changes were needed (Quinn, 2016). On the specific question of 'a financial burden' on public authorities it was felt not appropriate to introduce fees for requests, over and above the existing narrow circumstances in which a requestor can be currently charged for disbursement costs. The government argued that the introduction of new fees would lead to a reduction in the ability of requesters, especially the media, to make use of the Act and believed that transparency could help save taxpayers' money, by driving out waste and inefficiency (see Hansard House of Commons Ministerial Written Statement - HCWS566 1 March 2016).

\section{Using FOI}

Academics and other researchers saw a potential to conduct research using the law. Savage and Hyde (2014) contended that utilising the FOIA enabled individual researchers to gain access to information that is often only available to large funded projects. They argued that researchers have yet to use the FOIA to its full potential and that the 'FOIA is a powerful tool available to researchers' (Savage and Hyde, 2014, p.315). Yet despite this, social research on 
FOI is still perceived to be in its infancy (Savage and Hyde, 2014; Worthy, 2010). Indeed, Hazell, Bourke and Worthy (2012) have shown that very few people make FOI requests to Parliament or any other UK institution.

Our requests to the police were not the first time researchers had used the FOIA in this way. As with previous research we have already been successful in gaining access to information under the FOIA. We therefore decided to adopt this methodological approach because of this relative success. The experiences we examine in this paper, however, suggested a degree of caution to researchers who may seek to use the FOIA to gain data from the police. Although previous research has demonstrated the benefit of using FOI for data collection, we argue that using the Act should be done with greater awareness of the problems and barriers of gaining reliable data. These barriers include inordinate costs of retrieval that mean public bodies can refuse to search because of poor and inconsistent record keeping. The 'inconsistent' record keeping, for example, may mean the 43 police forces of England and Wales, may maintain records on the same subject in very different ways meaning the information provided cannot be collated into a meaningful whole. We also found that despite the statutory requirement to disclose information some public bodies (in our case the police) simply did not respond and did not provide the information requested. This therefore raised questions about the fundamental principles upon which FOI laws are introduced, as well as raising concerns about the principles of accountability, transparency and openness of public services.

\section{FOI requests on the use of ASBOs against sex workers}

This article stems from a request made by the authors under the Freedom of Information Act to gain information in respect of Anti-social behaviour orders available under the Crime and 
Disorder Act 1998. This request sought to determine the number of ASBOs made each year, and imposed on sex workers in each police constabulary in England and Wales since the act became law, the reasons for use of this law and the outcome of the use of this section of the Act. This request was sent to all 43 police forces in England and Wales, and then subsequently to 10 local authorities and the HM Courts and Tribunal Service.

Anti-social behaviour orders were introduced in 1998 by the Crime and Disorder Act. These orders were designed to tackle behaviour not deemed to constitute a criminal offence, by that which is problematic enough to cause 'alarm and distress' and thus requiring formal intervention. Although there was never any stated intent to use them to deal with street sex workers, the potential use of the order to respond to 'the nuisance and misery that prostitution can cause to local residents and businesses' (Home Office, 2000:1), was soon realised. ASBOs were repealed and replaced by Injunctions through the Anti-social Behaviour, Crime and Policing Act 2014 Part 1, and came into effect incrementally in 2015. Kingston and Thomas (2017) argue that the new powers contained within the Act will be used to deal with street sex workers.

In October 2014 we made FOI requests to all 43 police forces in England and Wales to gain data on:

1. The number of times each year, S.1 of the Crime and Disorder Act 1998 had been used against prostitutes/sex workers in their area since the act became law.

2. Details of the use of this section of the Act e.g. reasons for its use.

3. The outcome of the use of this section of the Act, i.e. nature of police or court disposal

The majority ( 27 or $62.8 \%$ ) of constabularies responded by stating that the request exceeded time and money allowances. 
For those constabularies that identified that our request for information would exceed the threshold for time and money allowances, they also stated they would not be able to perform the type of search for a number of reasons. Barriers to data retrieval posed by data management were the main reasons why police constabularies claimed that they were unable to undertake the relevant searches. The most common reason given for this was that the information was 'not recorded centrally' (10 constabularies, 37\%). As one explained, 'We will need to approach each of the 13 divisions to get the information' (Greater Manchester). Other constabularies ( 4 or 14.8\%), such as Surrey, claimed that the information was 'not held in an easily retrievable format' because of the 'period covered by the request and there is no relevant searchable field on the Constabulary's systems which would enable us to retrieve this information'. For six constabularies $(22.2 \%)$, these retrieval problems were related to changes in recording systems over the period requested. As Gwent explained 'Since 1998, Gwent Police have recorded crime on three systems', while Cleveland police noted that 'no records were kept' prior to 2007. For Norfolk constabulary the boundary changes for its Operational Partnership Teams had changed during the period, which meant that the information 'will have been recorded on different databases'.

For these reasons 15 constabularies (37\%), stated that the only way they would be able to provide the information would be to undertake a 'manual search' of 'associated databases' (Hertfordshire), 'force archives' (Staffordshire), 'each of the 13 districts' (Kent) and 'all crime/incident logs, which runs into the tens of thousands' (Wiltshire). Northumbria police stated that this would 'involve asking all officers and staff to interrogate email systems [and] paper based documents'. As a result of these difficulties some police constabularies stated that these searches would exceed the financial threshold and provided calculations on the potential cost implications. For example, London Metropolitan police stated that 'One 
borough advised me that they had issued 640 records ... It would take 10 minutes to peruse each record in order for this borough to answer question 1 only, it would take 106 hours'.

In response to these issues, four constabularies suggested that we contact the local council, magistrate's courts, Ministry of Justice, Crown Prosecution Service, or HM Courts and Tribunal service. Merseyside police explained that 'Magistrates court ... local authorities or HM Court Service are better placed to provide the information you seek'. Likewise Thames Valley police identified that 'ASBOs are issued by Magistrates courts and therefore the Ministry of Justice may be able to assist you further'.

Phoenix (2008) suggested there was no formal guidance given to the police to record the grounds upon which ASBOs are given to sex workers, and thus any attempt to gain statistics would lead to reliable data. However, it is worth noting at this point that formal guidance from the Home Office has long since recommended that details of ASBOs should be recorded on the Police National Computer (PNC) to enable 'police forces to effectively enforce breaches' of the ASBO (Home Office et al, 2003: 45 and 49-50). As the Home Office identifies 'The obtaining of the order is not the end of the process. The order must be monitored and enforced.' (ibid, 45). In fact, it is hard to see how any enforcement could ever take place without such recording having taken place. The implication is that those forces who said the information was not easily retrievable might have problems in actually enforcing the ASBOs in addition to being unable to respond to FOI requests.

\section{Further Requests}

Taking forward these suggestions we sent requests for information to the Ministry of Justice and as a starting point, 10 of the largest local authorities (LAs). Our initial request to HM Courts and Tribunal Service similarly led to a refusal of information on the grounds that the 
cost threshold had been exceeded. Out of the 10 LA's contacted, nine responded and one LA never replied to our email. Seven of the LA's replied saying they did not have any information or data and that we should contact the police and two suggested contacting local and district councils. One LA (Birmingham) stated that its legal services believe from 'recollection' that, in total, proceedings have been taken against approximately eight female sex workers. West Sussex stated they have not used the act against sex workers since its introduction. Given the responses from LAs, we initially decided to go back to seven constabularies who specifically claimed they could not do the searches due to time and money restrictions, to ask for more information but over fewer years.

We reduced our requests to five years and then if we were still informed it would exceed the limit we decided we would reduce the request to one year. Out of the seven constabularies contacted only three responded to our additional request. West Yorkshire police stated that because they had 920 ASBO's recorded 'At a moderate estimate of 2 minutes per record, this would involve some 30 hours work.' Hertfordshire reduced the search to 5 years and found one result for a breach of an ASBO in 2008. North Wales completed a search, which found zero results. The remaining still claimed it was not possible and gave reasons similar to this response from Merseyside Police:

“As Merseyside Police do not hold a central database listing all Anti-Social Behaviour Orders, the search process for the information would be exactly the same whether 15 years' data is being sought or just 6 months - we would still have to manually review every nominal record on the system to see if an individual is the subject of an ASBO. So unfortunately, reducing the timescale does not make this application manageable within the FOI time/cost limit." 
Based on the varied and inconsistent responses of the seven constabularies we re-contacted, we decided not to request information on the use of ASBOs from the other constabularies.

\section{No Data}

Despite twenty constabularies stating that data management issues meant that they were unable to undertake the relevant searchers, ten constabularies $(23.2 \%)$ undertook the searches and responded that they had no data to provide. Responses ranged from 'no information held' (Lincolnshire), to 'we have been unable to identify any use of S.1 of the Crime and Disorder Act 1998 (City of London). West Mercia police explained that they 'they are not aware of ... using the legislation against sex workers', whilst Avon and Somerset noted 'we do not issue ASBOs to sex workers ... If a sex worker is charged to court, we request Engagement and Support Order sentences [these are] a more constructive option to an ASBO ... to help them find a way out of it'.

\section{Data on ASBO use}

Of the 43 constabularies contacted, and importantly despite the vast majority stating that they were unable to conduct a search for data due to data management issues, five constabularies (11.6\%) provided us with some information on the number of ASBOs obtained in relation to sex workers. According to Derbyshire police, two ASBOs had been issued 'against a street sex worker and one against an individual for persistent loitering/soliciting' since the introduction of the Crime and Disorder Act in 1998. They also highlighted that ASBOs were no longer being used and that in the first instance, ESO would be used 'before an ASBO was considered [because] they are deemed to be a positive tool'. Likewise, South Yorkshire police sought to stress that ESO's are being used before ASBOs, but were only able to 
provide partial data. As with other constabularies, the data was not held in a central location. However, in this instance the officer contacted the four districts of the constabulary. All but the district of Doncaster returned a search of 'nil' use. Doncaster identified that since January 2013 three ASBOs had been issued, but that since November 2013, following a 'DMBC secured tender via the 'Changing Lives' Programme, ESOs being used.' Nottingham identified that:

\footnotetext{
'Since the legislation was introduced, 62 ASBOs have been obtained relating to women involved in street level prostitution ... Although 62 ASBO's have been obtained using this legislation, there have only been 50 different individuals who have received one. Of these 50 individuals, 35 have breached it at least once. These 35 individuals account for 412 breaches between them which all resulted in arrests and some of which resulted in charges.'
}

Humberside also provided data on the number of breaches of ASBOs (seven) since the law was introduced, but not on the number issued. Finally, Cleveland police was only able to provide partial data since 2007 as 'Prior to 2007 no records were kept'.

Based on the varied responses we received from the police and the estimated hours it was claimed it would take to undertake the searches, we decided not to appeal against the denial for information as we felt our appeal would be rejected on the basis of an excessive burden. An example of a requester appealing against the denial of police information based on costs can be found in the case of Mohammed Hassan $v$ Information Commissioner (Additional Party Chief Constable of South Wales Police) EA/2013/0264 03/06/2014; the case was dismissed (HM Courts \& Tribunal Service, 2014). 


\section{Discussion}

Despite beginning this research with the hope that we would gain information on the number of ASBOs issued by the police to sex workers, instead we found that the data on ASBOs was so varied and incomparable it was not possible to explore ASBOs in any depth. However, what our project did show was that there are considerable differences between how constabularies respond to FOI requests; with some providing information relatively quickly after a first request, whilst others have been unable to provide the information requested because many constabularies claimed that the work needed to retrieve the data would exceed a financial threshold stipulated in the law. For the majority of constabularies we contacted, barriers to data retrieval posed by data management issues meant that we were not provided with the information we requested because it was claimed, the work needed to retrieve the information would have exceeded the number of hours set as a threshold for completing the work.

Consequently, questions regarding how the cost of complying with FOI is calculated by the police should be the subject of greater scrutiny given the variations in the police's responses to this FOI request. These variations seem related to how constabularies' data is stored, managed and communicated, and thus calculations of hours of work cannot be comparable across constabularies. Therefore, rather than the provision of data being costed on hours worked, what the FOIA does not take into account are the internal complexities that mean access to data is institutionally cost bound. Transparency and accountability of the police is thus fractured and plagued by regional variants.

These institutional variations are not limited to the police. Previous research on attempts to estimate the cost of FOI compliance has demonstrated the different ways that FOI costs are calculated. Cherry and McMenemy's (2013, p.261) research with 26 councils, found that of the four councils (13\%) that did attempt to provide an estimate, their calculations and 
methodology varied considerably. The majority (87\%) of councils contacted did not provide an estimate of the cost, with reasons such as: not having a dedicated FOI team or individual and no centralised FOI recording. As with the findings of Burt and Taylor's (2009) research, FOI compliance was often seen as an 'add-on', rather than being a dedicated person's job responsibility. Thus as Cherry and McMenemy (2013, p.263) argue, 'the lack of any statutory duty to record cost data also seems like an oversight on the part of the policy makers, since it is being used as a potential measure of the performance of the effectiveness of the legislation.'

The reasons we were given for not providing information mirrors what has been explored in previous research with local authorities. So, for example, Shepherd et al's (2010) study of 19 local authorities demonstrated diverse approaches to records management and inconsistencies in the quality of information provided. For some local authorities restructuring and reductions in office space meant that FOI officers did not know where in the organization the information was being held. For others, the de-centralised nature of local authorities meant that retrieving the information was not straightforward and records management was poor (Shepherd, Stevenson \& Flinn, 2011). Technological methods of recording data meant that certain authorities were unable to fulfil the request for information in Savage and Hyde's research (2013). This meant, as in our case, that some local authorities could not find the information whilst others could.

Likewise, police research has highlighted the problems of de-centralized police divisions within constabularies and the problems this has for decision-making and officer supervision (Butler, 1984). In addition, restructuring and reductions in office space has been witnessed in the police context as cuts to public funding has led to the closure of some police stations. According to research by Ensor $(2012$, p.1) 1,017 police stations have been closed in the UK since 2000, with some estimations that on average 65-60 police stations are closed 
each year in the UK (Smith \& Somerville, 2013, p.348). According to a report in the Mail Online (2017), that was not disputed in a Home Office response (2017), the number of police stations has halved in the past ten years. Although not identified in our research as being a direct result of funding cuts, it is likely that this will have impacted on the police's ability to provide information. Indeed Payne-James et al (2014) suggest that in the current economic climate public bodies, such as the police pay diligence to the cost of providing such information when considering the allocation resources. As the Constitutional Unit (2012, p.3) have argued 'Resources are vital and are likely to be the Achilles' heel of FOI'.

The 'cost' of FOI requests to government departments has become an area of contention as the calculated cost of implementing and complying with this legal requirement has been estimated to be in the millions. For example, the UK government's Department of Constitutional Affairs commissioned Frontier Economics to examine the cost of administering FOI legislation. Its report found this to be in the region of $£ 35$ million per year (Frontier Economics, 2006, p.3). Therefore, it may be unsurprising that public authorities feel that the cost is too high, an issue that is exacerbated by a view that the range of activities that can be included in cost calculations is not extensive enough (Savage \& Hyde, 2014). A recommendation of the Frontier Economics report was to change the ways in which the costs of requests was calculated as a means of discouraging requests. As they claim the rationale for such an alteration of the law would be to deal with 'requests that are not in the spirit of the Act' (Frontier Economics, 2006, p.3).

Internationally there has been concern that governments are increasingly using exemptions, such as the excessive 'cost' of compliance, as a means of limiting the use and 
impact of FOI laws (Cherry \& McMenemy, 2013). ${ }^{3}$ These concerns are unsurprising given that FOI have been introduced in the spirit of transparency and the accountability of public bodies (Savage \& Hyde, 2014). The impact of these exemptions can be seen in Ireland, five years after FOI law was implemented, whereby fees introduced subsequently led to a $50 \%$ reduction in the number of FOI requests made (McDonagh, 2006, cited in Hazell \& Worthy, 2010). Similarly in Australia after three years of support, the law was revised to include an increase in fees which deterred requesters and led to the gradual neglect of FOI by governments (Hazell \& Worthy, 2010).

The ability to utilise a cost calculation exemption to either deny access to information or as a 'legitimate' response, rather than explaining that staff shortages has led to patchy data recording, may be pertinent to police constabularies given the significant cuts to police budgets in recent years. Indeed, in the Comprehensive Spending Review 2010 police funding from the UK government was reduced by $20 \%$ between 2011 and 2015 (HM Treasury, 2010, p.10) and when taking into account other income contributions a reduction of $25 \%$ has been seen between 2010-11 and 2015-16 (National Audit Office, 2015, p.4). Given that the police's main source of income is the central government grant (Johnston \& Politowski, 2016), these unprecedented cuts have meant that police have had to reconsider their priorities, and has led to a sense of uncertainty within constabularies and questions asked about 'what form policing will take post-austerity' (Millie, 2013, p.52). In this sense, it is likely that the police's compliance with FOI with be fraught with difficulties. As police funding is cut, the 'cost' of FOI compliance increases.

\footnotetext{
${ }^{3}$ The areas covered by exemptions can include commercial secrets, personal privacy, public security, the protection of national security for example, which has led to this being one of the most debated aspects of FOI laws (Ackerman \& Sandoval-Ballesteros, 2006).
} 
Methodologically Holsen has described the exact cost of FOI compliance is 'virtually impossible to calculate' (Holsen, 2007, p.52). Previous research has highlighted that this is because many government bodies do not record the number or nature of FOI requests, nor the cost of FOI compliance (Cherry \& McMenemy, 2013). In addition, others have noted that estimated costs may be biased and influenced by those undertaking or commissioning the research into FOI cost (ibid). Often it is claimed that rather than just merely protecting government secrets or public security for example, evidence of discretion and deliberate manipulation plague FOI laws. As Hazel et al (2012) have identified, political institutions and organizations with strong cultural attitudes are often resistant to change and regulation and may seek to preserve existing procedures, thereby making reform problematic. As Worthy (2010, p.563) describes 'the power that flows from secrecy, and is lost through openness, makes FOI a particular potent threat'.

A lack of support and investment in data management software and staff has also been identified as a barrier to FOI requests in research with local authorities. A lack of senior management support to be more proactive than reactive with data management in terms of investing in software and staff has been noted (Shepherd et al, 2010). In some instances FOI responsibility often fell on one individual which meant that managing FOI requests became unwieldly. In other cases cultural attitudes and general resistance to FOI have been identified (Burt \& Taylor, 2007). As Shepherd et al (2010, p.342) found in some instances 'FOI and particularly records management were not deemed to be frontline issues'. Thus, the words 'irritating' and 'annoying' were used when discussing FOI by some local authority employees (ibid, p.342). Burt and Taylor (2007) found in their research that people were often too busy to find time to deal with FOI requests despite them being legal obligations. This led Shepherd et al (2010) to conclude that successful compliance was people-dependent 
and even with robust records management systems attitudes, communication problems and a skills gap would hamper FOI compliance.

These barriers have also been observed internationally in Canada, Australia and the USA. Roberts (2005) demonstrated that Canadian officials had developed internal practices and technologies that would hinder the FOI request process. These hidden routines are concealed from public view, yet play a vital role in shaping the meaning of the 'right' to information in Canada:

On the face of it, the law may appear to guarantee equal treatment for all requests - but in actual practice, journalists and partisans are treated differently. In general, their requests take longer to process. Statutory deadlines are more likely to be overrun. Relevant documents will be reviewed more closely. Special efforts will be made to enhance the government's capacity to rebut anticipated criticisms flowing from disclosure.

Likewise in Australia, Snell (2001) has shown how the tactics employed in government departments have been used in an attempt to manage the flow of sensitive information and the potential effects of the release of that information. In the United States Nader (1970) observed tactics whereby FOI officials would delay replying for several weeks, reply in an obscure way, claim that the provision of information may lead to retaliation against them, or refuse to provide information because of records management problems. Summarising what he saw as the problems with FOI laws:

government officials at all levels in many of these agencies have systematically and routinely violated both the purpose and specific provisions of the law. These violations have become so regular and cynical that they seriously block citizen understanding and participation in government. Thus the Act, designed to provide 
citizens with tools of disclosure, has been forged into a shield against citizen access. There is a prevailing, official belief that these federal agencies need not tolerate searching inquiries or even routine inquiries that appear searching because of their infrequency. (Nader, 1970, p.2)

Although it cannot be stated with any certainty that our inability to retrieve the data requested was the result of attempts to obfuscate, or delay to prevent disclosure, research has for many years noted that the police has historically been a secretive organisation (Ruiz, 2015) and are often suspicious of 'outsiders' (Reiner, 2010). Questions as to the transparency, openness and accountability of the police in dealing with FOI requests should therefore be raised. Previous research by Crawford (2009:16) examined the use of dispersel powers to tackle anti-social behaviour and found 'significant inconsistencies in police recording practices'. Indeed, as we discovered following our FOI requests to determine the use of S.14 of The Policing and Crime Act 2009 by the police across England and Wales (Kingston \& Thomas, 2014), subsequent research on the use of S.14 that followed our methodological approach were provided with completely different data from the same forces, and both studies despite being conducted in a similar time period also retrieved information from some forces that did not match (Matolcsi, 2015; Mulvihill, 2015). Whether this was an officer's error, or a system malfunction is unclear, but it clearly raises questions about both the reliability of FOI data provided by the police and their ability to deal with FOI compliance in an accurate manner.

The problems and challenges of gaining access to information should therefore be put under scrutiny. Roberts (2001) argues citizens should be under an obligation to monitor the conduct of agencies and their adherence to FOI legislation. Likewise, Cherry and McMenemy (2013) state that it is only through complaints or appeals that anyone will know whether organisations are complying with FOI legislation. As Roberts (2001, p.262) states 'citizens 
cannot evade their own responsibility for ensuring that these agencies do their work properly'.

Those whose legislative role it is to inspect and report on the efficiency and effectiveness of police constabularies, such as the HM Inspectorate of Constabulary and Fire \& Rescue Services (HMICFRS, formally HMIC), may therefore also wish to investigate the police's FOI compliance and how costs are calculated. Given the HMICFRS has the power to inspect police organisations and functions to ensure that agreed standards are achieved and maintained, good practice is spread and performance is improved (Mawby \& Wright, 2005), we believe the issues raised in ours and previous research on FOI compliance raises significant questions about the ineffective and inefficient ways data is recorded and managed. These institutionally specific inefficiencies undermine the police's ability to be transparent and provide access to data. Likewise, the time police personnel spend attempting to process FOI requests is likely to not be cost effective and is a drain on public resources; an issue which may be of interest to the HM Inspectorate of Constabulary and The Home Office. In a context of increased budget cuts and scarce resources (Loader, 2016), this has led some to argue that policing is in 'an era when [police] accountability becomes reduced to accountancy' (Rogers, 2014). The calculation of costs for FOI compliance is a useful example of this point.

\section{Conclusion}

This study has found that although the 'cost' of complying with FOI law was identified as the reason why information requested would not be given, when we explore how this cost is calculated by police constabularies we uncovered that 'cost' is a 'metric' for institutional barriers and limitations in data recording. Rather than being comparable costs across constabularies, the decentralised nature of data recording and data management problems 
varied considerably. This meant that cost calculations were constabulary specific. Thus, the apparently clear charge fee of $£ 25$ per hour in order to cover the cost of the time spent by staff in searching for and providing the information requested, is much more complex a calculation than hours worked and is not based on like-for-like hours. Instead it is underpinned by constabulary specific issues that have only become visible following a request for information. What is neglected in these 'cost' debates is the cost of not addressing the barriers and limitations constabularies face, such as data management software, centralised data storage and adequate staff and investment in FOI compliance. Clearly, having inadequate software and retrieving data from multiple sources is both time and resource intensive. Indeed, in a period of austerity it is likely that these issues that underpin 'cost' calculations are likely to worsen.

Wald's (1984:649) observations of two decades ago are still pertinent today: 'the history of the Freedom of Information Act ... is a chronicle of the perils and problems of translating rhetoric into performance'. Furthermore, Ackerman and Sandoval-Ballesteros (2006:105) note that FOI laws without enforcement 'is doomed to be a dead letter', since the culture of bureaucracy typically works against the automatic implementation of openness. We argue that the reasons given for not providing information requested demonstrate that not only does rhetoric not translate into performance by policy makers who set the financial threshold, but also by institutions whose systems and processes make the retrieval of information problematic. Previous research has demonstrated the barriers to data retrieval and data accuracy, such as data management problems, institutional policies, staffing problems, as well as institutional or staff data release avoidance techniques. All of these were visible in our findings. Yet, very little attention has been paid to police constabularies' refusal to provide information. This article begins to address this gap in the literature by exploring the reasons why our request for information was rejected. 
This study has also identified some of the problems with using FOI laws as a research tool; such as the inconsistencies in data provided, the variations in responses and the potential lack of information requested. As Lee $(2005$, p.6) has indicated, researchers are relying on the information made available and therefore take on a 'passive role' in relation to research design. Relying on secondary data gained from organisations such as the police can often lead to delays in gaining information. The quality of data may also be questionable. Indeed, relying on FOI officers who may not fully understand the nature of a research project, or the intentions for which the data would be used, may lead to officers' discretion. We thus challenge suggestions made by some who claim that FOI provides a valuable resource that can be exploited by researchers because as Lee (2005, p.15) describes 'It is the scope of exemptions to the Act, how they are framed and interpreted, and their interrelations that establishes the limits of open government.' We therefore urge researchers to consider the methodological benefits and limitations of using FOIA as a methodological tool to gain access to information held by the police.

\section{References}

Ackerman, J. M., \& Sandoval-Ballesteros, I. E. (2006). The global explosion of freedom of information laws. Administrative Law Review, 85-130.

Birkenshaw, P (2010) Freedom of Information: The Law, the Practice and the Ideal, Cambridge: Cambridge University Press.

Burt, E. \& Taylor, J.A. (2009). Freedom of information and Scottish local government: continuity, change and capabilities in the management of information. Local Government Studies, 35 (2), 181-196. 
Butler, A.J.P. (1984). Police Management. Brookfield: Avebury Publishing Co.

Button, M., Blackbourn, D., \& Tunley, M. (2014). 'The Not So Thin Blue Line After All?' Investigative Resources Dedicated to Fighting Fraud/Economic Crime in the United Kingdom. Policing, 1-14.

Cabinet Office. (2016). Independent Commission on Freedom of Information report (press release). 1 March. Retrieved from:

https://www.gov.uk/government/organisations/independent-commission-onfreedom-ofinformation [accessed 3 March 2016].

Cherry, M., \& McMenemy, D. (2013). Freedom of information and 'vexatious' requests The case of Scottish local government. Government Information Quarterly, 30 (3), 257-266. College of Policing. (2015). Information management: Freedom of information. Retrieved from: https://www.app.college.police.uk/app-content/information-management/freedom-ofinformation/ [accessed 13 September 2010].

Constitutional Unit. (2012). Written evidence from the Constitutional Unit, University College London. Retrieved from:

http://www.publications.parliament.uk/pa/cm201213/cmselect/cmjust/96/96we09.htm [accessed 04 March 2016].

Connett, D. (2015). Government review of FoI criticised as 'a step back' that could 'water down' the Act. The Independent. 20 July 2015.

Crawford, A. (2009). Criminalizing Sociability through Anti-social Behaviour Legislation: Dispersal Powers, Young People and the Police. Youth Justice 9(1): 5-26. 
DCA (Department of Constitutional Affairs). (2004). Code of Practice on the discharge of public authorities' functions under Part 1 of the Freedom of Information Act 2000, issued under section 45 of the Act. HC33 TSO: London

Duchy of Lancaster. (1997). Your Right to Know: the government's proposals for a Freedom of Information Act. Cm 3818 December TSO: London. Retrieved from https://www.gov.uk/government/publications/your-right-to-know-the-governmentsproposals-for-a-freedom-of-information-act accessed 6 August 2015 [accessed 30 March 2016].

Ensor, J. (2012). End of 'bobby on the beat' as third of police stations close. Telegraph. 18 March 2012. Retrieved from: http://telegraph.co.uk/news/uknews/law-and-order/9150425/ End-of-bobby-on-the-beat-as-third-of-police-stationsclose.html [accessed 30 August 2016]. Feld, B.C. (1991). Justice by Geography: Urban, Suburban, and Rural Variations in Juvenile Justice Administration. The Journal of Criminal Law and Criminology, 82 (1), 156-210. Frontier Economics, (2006), Independent Review of the Impact of the Freedom of Information Act, a report for the Department for Constitutional Affairs, London: Frontiers Economics ltd. Hazell, R., Bourke, G., \& Worthy, B. (2012). Open House? Freedom of Information and its impact on the UK Parliament. Public Administration, 90(4), 901-921.

Hazell, R., \& Worthy, B. (2010). Assessing the performance of freedom of information. Government Information Quarterly, 27(4), 352-359.

Hazell, R., Worthy, B., \& Glover, M. (2010) The Impact of the Freedom of Infomration Act on Central Government in the UK, Basingstoke: Palgrave Macmillan. 
HM Courts \& Tribunal Service (2014) Guidance - Information rights: appeal against the Information Commissioner, available at http://www.informationtribunal.gov.uk/ [accessed 31 August 2015].

HM Treasury. (2010). Spending Review 2010, Presented to Parliament by the Chancellor of the Exchequer by Command of Her Majesty, October 2010. Retrieved from: https://www.gov.uk/government/uploads/system/uploads/attachment_data/file/203826/Spendi ng_review_2010.pdf [accessed 30 August 2016].

Holsen, S. (2007). Freedom of Information in the UK, US and Canada, The Information Management Journal, 41 (3), 50-55.

Home Office (2003) A Guide to Anti-Social Behaviour Orders and Acceptable Behaviour Contracts, Retrieved from:

http://webarchive.nationalarchives.gov.uk/20100408141132/http://www.crimereduction.hom eoffice.gov.uk/asbos/asbos9.pdf [accessed 20 October 2017].

Home Office (2017) Response to Mail on Sunday article on police station closures, Information Commissioners Office (2015) Definition Document for Police Forces https://ico.org.uk/ [accessed 31 August 2015].

Johnston, N., \& Politowski, B. (2016). Police funding. House of Commons Briefing Paper, Number 7279, 25 February 2016. Retrieved from:

http://researchbriefings.files.parliament.uk/documents/CBP-7279/CBP-7279.pdf [accessed 30 August 2016].

Katz, J. M. (1970). Games bureaucrats play: Hide and seek under the freedom of information act. Texas Law Review 48(7), 1261-1284. 
Kingston, S., \& Thomas, T. (2014). The Police, Sex Work, and Section 14 of the Policing and Crime Act 2009. The Howard Journal of Criminal Justice, 53(3), 255-269.

Kingston, S., \& Thomas, T. (2017). The Anti-social Behaviour, Crime and Policing Act 2014: implications for sex workers and their clients. Policing and Society, 1-15.

Kronman, A. (1980). The Privacy Exemption to the Freedom of Information Act. The Journal of Legal Studies, 9 (4): 727-774.

LaMay, C., Freeman, R., \& Winfield, R. (2013) Breathing life into freedom of information laws: the challenges of implementation in the democratizing world, available at: https://www.cima.ned.org/wp-content/uploads/2015/02/CIMAFreedom_of_Information_ISLP_09-10-13.pdf [accessed 4 Nov 2017].

Lee, R. M. (2005). The UK Freedom of Information Act and social research. International Journal of Social Research Methodology, 8(1), 1-18.

Loader, I. (2016) Changing climates of control: The rise and fall of police authority in England \& Wales, in M. Bosworth., C.Hoyles \& L. Zedner (eds) Changing Contours of Criminal Justice, Oxford: Oxford University Press, 3-14.

Lord Bridges (2015) Written statement to Parliament Freedom of information: new Commission, available at: https://www.gov.uk/government/speeches/freedom-ofinformation-new-commission [accessed 3 June 2016].

Matolcsi, A. (2015). Implementation in England and Wales of the Section 14 of the Policing and Crime Act 2009 since its coming into force in 2010. Paper presented at the meeting of the Prostitution Policies: Understanding Scales and Cultures of Governance (Prostpol) Conference Troubling prostitution: Exploring intersections of sex, intimacy and labour, Vienna, Austria, 1-18 April, 2015. 
MailOnline (2017)

Mawby, R., \& Wright, A. (2005) Police Accountability in the United Kingdom, available at: http://www.humanrightsinitiative.org/programs/aj/police/res_mat/police_accountability_in_u k.pdf [accessed 3 June 2017].

Millie, A. (2013). What are the police for? Re-thinking policing post-austerity. In J. M. Brown (Ed.). The Future of Policing. London: Routledge, 52-63.

MoJ (Ministry of Justice). (2015a). Court and Tribunal Fees: the Government response to consultation on enhanced fees for divorce proceedings, possession claims, and general applications in civil proceedings and Consultation on further fees proposals. Cm 9124, August, London.

MoJ (Ministry of Justice). (2015b). Court and Tribunal Fees: the government responses to consultation on further fees proposals. Cm 9181 December, London.

Mulvihill, N. (2015). A critical discourse analysis of the Parliamentary debates on criminalising sex purchase in England and Wales 2006 - 2009. Paper presented at the meeting of the Prostitution Policies: Understanding Scales and Cultures of Governance (Prostpol) Conference Troubling prostitution: Exploring intersections of sex, intimacy and labour, Vienna, Austria, 1-18 April, 2015.

Nader, R. (1970). Freedom from Information: The Act and the Agencies. Harvard Civil Rights-Civil Liberties Law Review, 5, 1-15.

National Audit Office. (2015). Financial sustainability of police forces in England and Wales. Retrieved from: https://www.nao.org.uk/report/financial-sustainability-of-policeforces-in-england-and-wales/ [accessed 30 August 2016]. 
Quinn, B. (2016). Review decides not to change Freedom of Information Act. The Guardian. 1 March.

Payne-James, J. J., Rivers, E., Green, P., \& Johnston, A. (2014). Trends in less-lethal use of force techniques by police services within England and Wales: 2007-2011. Forensic Science, Medicine, and Pathology, 10(1), 50-55.

Phoenix, J (2008) ASBOs and working women: A new revolving door?, in P. Squires (Ed) ASBO Nation: The Criminalisation of Nuisance, Bristol: The Policy Press, 289-303.

Reiner, R. (2010). The Politics of the Police. Oxford: Oxford University Press.

Roberts, A. S. (2001). Structural Pluralism and the Right to Information. University of Toronto Law Journal, 51(3), 243-271.

Roberts, A. S. (2005). Spin Control and Freedom of Information: Lessons for the United Kingdom from Canada. Public Administration, 83(1), 1-23.

Roberts, A. S. (2001). Structural Pluralism and the Right to Information. University of Toronto Law Journal, 51(3), 243-271.

Rogers, C (2014) Police accountability in the age of austerity, The Police Journal: Theory, Practice and Principles, 97(1) 1-2.

Ruiz, P. (2015). Police, Protester, Public: Unsettling Binaries in the Public Sphere. In E. Thorsen, D. Jackson, H. Savigny \& J. Alexander (Eds.), Media, Margins and Civic Agency (pp. 195-208). London: Palgrave Macmillan, UK.

Sagar, T. (2007). Tackling on-street sex work: Anti-social behaviour orders, sex workers and inclusive inter-agency initiatives. Criminology and Criminal Justice, 7(2), 153-168. 
Savage, A., \& Hyde, R. (2014). Using freedom of information requests to facilitate research. International Journal of Social Research Methodology, 17(3), 303-317.

Shepherd, E., Stevenson, A., \& Flinn, A. (2010). Information governance, records management, and freedom of information: A study of local government authorities in England. Government Information Quarterly, 27(4), 337-345.

Shepherd, E., Stevenson, A., \& Flinn, A. (2011). Freedom of Information and records management in local government: help or hindrance? Information Polity, 16(2), 111-121. Smith, R., \& Somerville, P. (2013). The Long Goodbye: A Note on the Closure of Rural Police-Stations and the Decline of Rural Policing in Britain. Policing, 7(4), 348-358.

Snell, R. (2001) Freedom of Information: The Experience of the Australian States - an Epiphany? Federal Law Review, 21, 343-358.

Vincent, D. (1998). The Culture of Secrecy: Britain 1832-1998. Oxford: Oxford University Press.

Wald, P. M. (1984). Freedom of Information Act: A Short Case Study in the Perils and Paybacks of Legislating Democratic Values. Emory Law Journal, 33, 649-683.

Worthy, B. E. N. (2010). More Open but Not More Trusted? The Effect of the Freedom of Information Act 2000 on the United Kingdom Central Government. Governance, 23(4), 561582. 